\title{
Contribution of Chinese and Indian tourism to Australia: A comparative econometric study
}

\author{
Tran Van Hoa (PhD) \\ Professor and Director, \\ Vietnam and East Asia Summit Research Program. \\ Victoria and Wollongong Universities, Australia.
}

\author{
Jo Vu (PhD) \\ Senior Lecturer, \\ Victoria University, Australia.
}

\begin{abstract}
Under the current widespread economic integration of new international trade theory, the world's two most populous countries, China and India, have achieved high growth, reducing poverty, increasing income and living standards and, as a result, provided good sources of much needed income-generating tourism to international destinations in recent years. The trend in rising tourism including education from China and India to Australia is exponential, and particularly important where the country's geographical, cultural and educational quality attributes are internationally key attractions. Appropriate studies of this trend and economic outcomes, with robust and reliable empirical findings for credible analysis have been inadequate to date. The project addresses this gap by proposing to investigate the economic contributions of China and India's tourism to Australia, and their determination for strategic international policy analysis. Significantly, this is done from an economic integration framework, which is also the expenditure (as opposed to production or income) perspective of the United Nations System of National Accounts 1993/2008. A multi-simultaneous equation model of endogenous Australian growth and Chinese and Indian tourism determination is developed. The model novelly incorporates gravity theory and classical consumer demand contributors, Ironmonger-Lancaster commodity attributes and Johansen policy impact add-and sub-factors explicitly in the economic integration framework, and is estimated by system methods with official economic and tourism 1992-2016 data. The findings will provide appropriate and much needed evidence-based inputs on the major economic integration contributors to Australia's growth, Chinese and Indian tourism causality to key stake-holders such as tourism policy-makers, analysts and operators for international strategic policy analysis and practical implementation.
\end{abstract}

Keywords: Australia's growth, Chinese and Indian tourism, economic integration theory, econometric modelling, strategic tourism policy, economic and trade policy.

JEL: C54, F15, F62, Z32, Z38

\section{INTRODUCTION}

As two major beneficiaries of global openness or also known as economic integration (WTO, 2019) and policy reforms, China and India, the world's two most populous countries, have achieved much in raising their living standards, reducing poverty and increasing income in the last few decades. An important outcome of this increasing income is that, coupled with their large population, it provides a major source of travelling consumers (tourists and international students) to attractive international destinations bringing with them substantial income, employment and infrastructure benefits as well as other non-negligible non-tangible gains. In the case of Australia for example, in the last few decades, the number of arrivals from China and India has grown exponentially and surpassed what has been known as the great Japanese tourist boom of the 1970s-1980s. In spite of these important developments, studies of the 
simultaneous economic impact of Chinese and Indian tourism on Australia and their comparative benefits especially in the economic integration framework for suitable tourism policy analysis and implementation have been very limited or even non-existent (see Tran et al, 2018 and Tran and Vu, 2018, for the case of China and Vietnam respectively. Pham et al., 2017 discuss China's visitors to Australia using a simple dynamic demand analysis).

The paper addresses this gap to provide advances in tourism research and to provide appropriate data-based tourism policy recommendations for globalised economy stakeholders with a focus on Australia vis-a-vis China and India. Section 2 contains a brief description of 1992-2016 data on growth and tourism conditions in the three countries and how they may be related. A model of simultaneous equations for Australia's endogenous growth, Chinese and Indian tourism determination and its special theoretical and empirical features is developed in Section 3. Section 4 reports the findings and their reliability features obtained by system estimation with 1992-2016 data. Tourism policy implications are derived and described in Section 5. Section 6 concludes.

\section{GROWTH AND TOURISM CONDITIONS IN AUSTRALIA, CHINA AND INDIA}

The patterns of growth in Australia (YC), China (YCCN) and India (YCIN) during 1992-2016 are given in Chart 1. From this chart, we note the high annual growth pattern of China since its WTO membership in 2001 and peaked in 2007 at 14.19 per cent just before the Global Financial Crisis (GFC). China's growth had been declining since this peak ending 6.7 per cent in 2016. The average annual growth was still a remarkable rate of 9.85 per cent. China's growth appears to be affected by the Asian Financial Crisis (AFC) of 1997/1998 and the GFC in 2008/2009. From the chart, India's growth appears consistently lower than China's growth and also more volatile during the whole 1992-2016 period. It had the peak of 10.26 per cent in 2010 after the GFC and 8.85 per cent in 1999 after the AFC. India's growth does not appear to be affected by the AFC but severely impacted by the GFC with a low growth of only 3.89 per cent in 2008. India recovered quickly however after this. On average, India's growth reached a good high of 6.83 per cent. Australia, as all other developed countries, is usually characterised as a country with low growth. In the chart, its growth was consistently below both India's and China's growth and was facing a continuously declining trend since 1993. Australia's growth reached its peak of 5.05 per cent in 1999 and has an average of 3.19 per cent during 19922016. As expected, Australia's growth was not impacted by the AFC but mildly by the GFC.

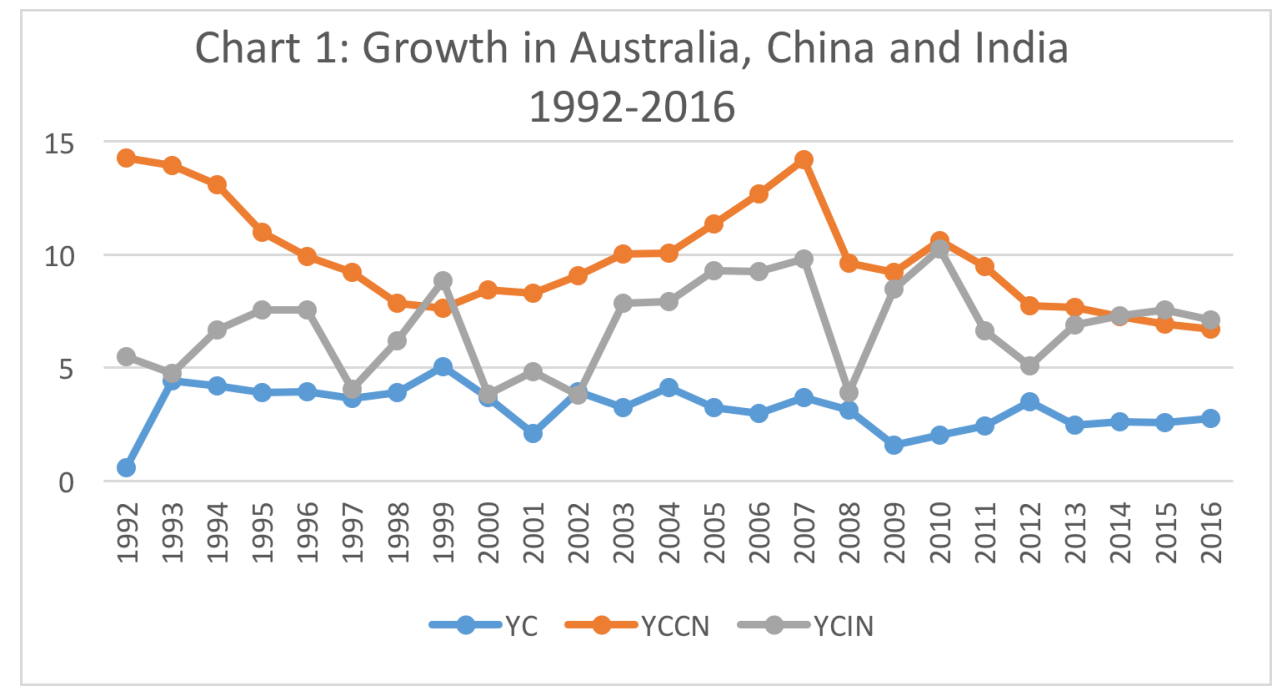

Source: USDA-ERS (2019) 
China's and India's tourism (in '000), that is, TCNT and TINT respectively, during 1992-2016 are depicted in Chart 2. From this chart, we note the exponential growth of China's tourism to Australia starting at 18.8 in 1992 and ending 1,199.1 in 2016. This trend was tempered mildly by the Iraq War in 2003 and slightly by the GFC. Its annual average was 332.7. India's tourism to Australia was slower than China's, starting at 8.5 in 1992 and ending at 259.9 in 2016. Its annual average was 85.8, about a quarter of China's. It did not seem noticeably affected however by any regional or global crisis and turmoil.

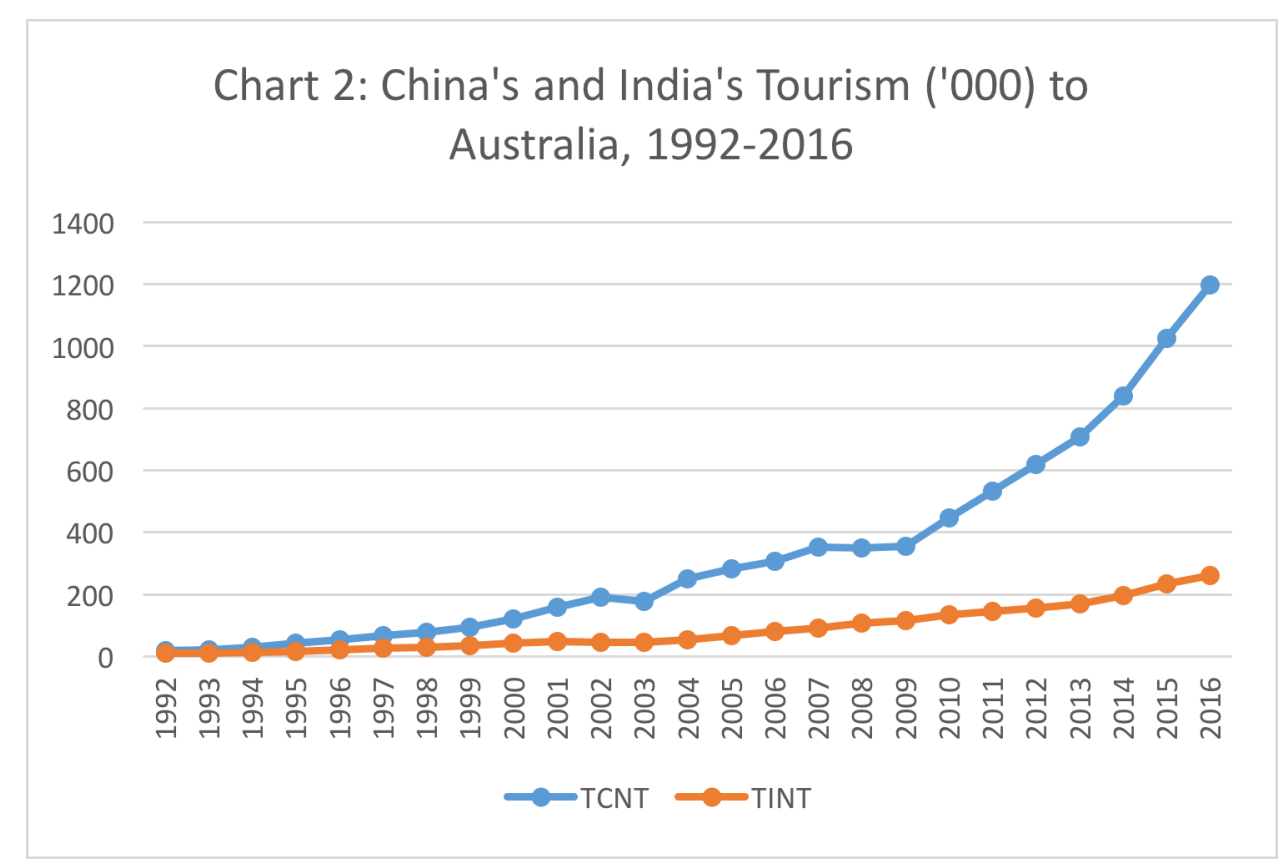

Source: ABS (2019)

The patterns of the three normalised major sources of growth in the framework of deep economic integration theory (WTO, 2019) for Australia during 1992-2016 are given in Chart 3. These sources are openness or commodity trade/GDP (TY), foreign direct investment/GDP (FDIY), and services/GDP (SY). In this chart, we note a moderate rising and volatile trend for TY with a peak of 34.20 per cent during the terrorist attacks in New York in 2001, a trough of 28.20 per cent after the Iraq War in 2004, and the highest peak of 35.30 per cent in 2009, indicating a strong and quick recovery after the GFC. Australia's openness had been declining since 2012 where it posted 33.40 per cent. FDI into Australia shows a fairly stable and low trend from 1992 till 2005 when it reached the peak of 5.88 per cent. Since the fall then, FDI had shown a modest rising trend reaching 3.54 per cent in 2016. In contrast to FDI, services appears to be a more dominant sector with a moderate growth till the AFC in 1998 at 16.89 per cent. Since 1999 however, services had been mainly declining but with a small pick-up of 9.38 per cent in 2016. In terms of their average importance, the mean values for TY, FDIY and SY for the period 1992-2016 are 31.36, 1.61 and 11.03 per cent respectively. 


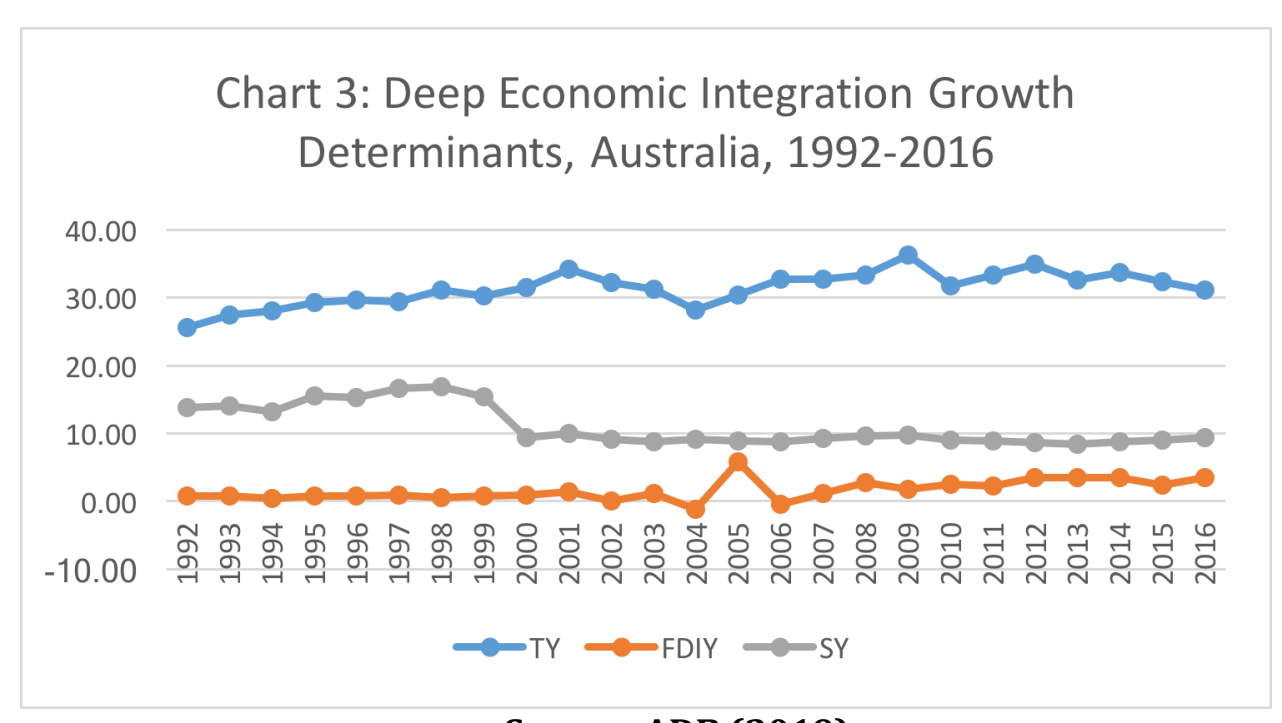

\section{Source: ADB (2019)}

Some major determinants of tourism such as the source countries' real exchange rates (purchasing power), RXRCN and RXRIN, and the destination country's costs of living or inflation (CPIC), in addition to deep economic integration factors, are given in Chart 4. In this chart, we note the low volatility of China's real exchange rate, due to the country's essentially pegged regime, and also Australia's low inflation rate in the last few decades, due to its stable monetary policy. In contrast, India's real exchange rate shows great volatility and slow and gradual decline, due to its flexible regime and reforms. All three indicators are characterised by a mild declining trend and a modest impact of the GFC.

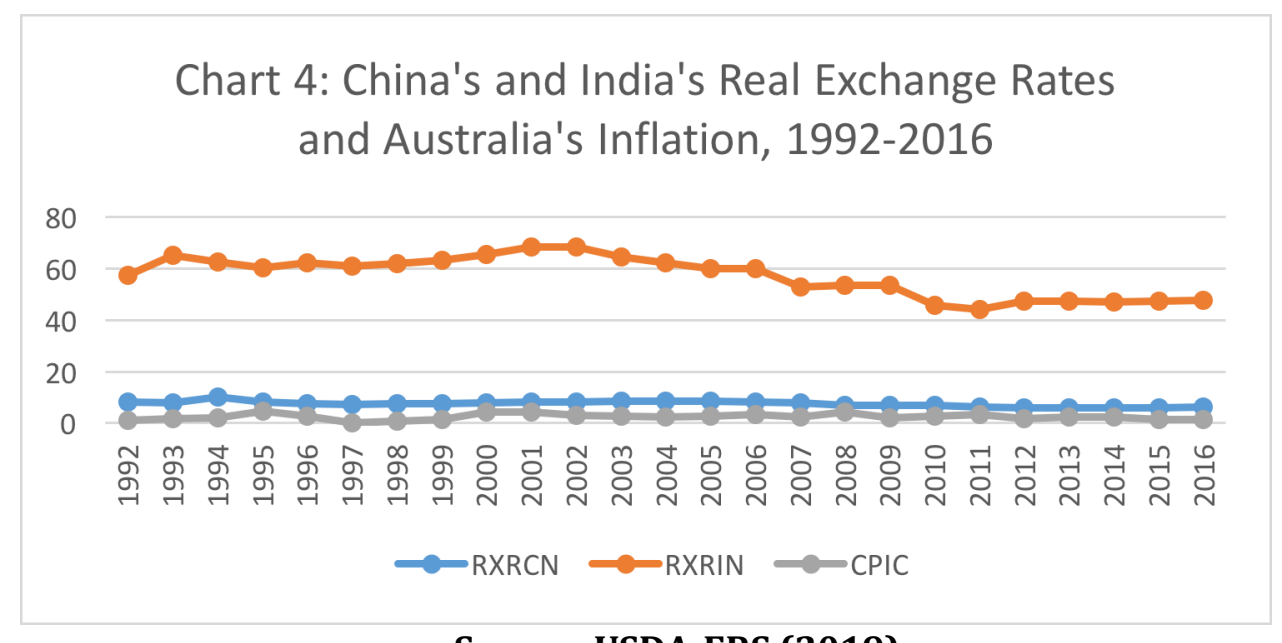

\section{Source: USDA-ERS (2019)}

The above indicators in Charts 1-4 describe the key variables that, in addition to other influencing determinants (described below), are relevant conceptually (Tran et al., 2018, Tran and $\mathrm{Vu}, 2018$ ) to our model of Australia's endogenous growth and tourism determination. At face value, they describe a complex system of possible interrelationships between key variables including especially the research questions: what is the contribution of China's and India's tourism to Australia and what makes the causal difference if any, and their possible substantive policy solutions. To unravel this complex interrelationship from the data in a rigorous way, we propose to investigate it by econometric analysis using the so-called Marshall-Haavelmo approach to simultaneous economic modelling. 


\section{A MODEL OF ENDOGENEOUS GROWTH AND TOURISM DETERMINATION FOR POLICY ANALYSIS}

As described earlier (see Tran et al., 2018), the development of a simultaneous-equation model for a growth-tourism causal study and policy analysis and under an economic integration framework (or System of National Accounts 1993/2008 expenditure) is conceptually based on three theories: (a) the basic growth-determination postulates of economic integration and regional trade agreements (WTO, 2019), namely, trade, FDI and services (including tourism), (b) gravity theory (including growth in origin and destination countries) (Frankel and Romer 1999) and the extended Ironmonger (1972)-Lancaster (1966) new consumer demand theory where potential factors affecting tourism via its characteristics or attributes are considered, and (c) Johansen (1982) policy-impact add- and sub-factors, such as domestic reform and external crises, that may affect simultaneously growth and tourism. This class of models has also been successfully applied and implemented as measured by modelling reliability criteria, such as that proposed by Friedman (1953) and Kydland (2006) where good prediction-reality compatibility or 'empirical fit' is a crucial credibility criterion (e.g., Tran 2002a, 2002c, 2004, 2005; Tran and Limskul 2013; Tran et al., 2018). For a survey of other existing approaches, see Song et al., (2012).

Thus, to provide substantive answers to our research questions, we propose to develop a model of three simultaneous equations in implicit form for Australia's endogenous growth, China's and India's tourism determination in the framework of deep economic integration theory (see Tran and Limskul, 2013; Tran et al., 2018) as follows:

$\begin{array}{ll}Y_{t}=F 1\left(a, O_{t}, F D I_{t}, S E_{t}, T C_{t} T I_{t} I_{t}, W_{t}, S_{t}\right), & t=1, \ldots, N \\ T C_{t}=F 2\left(b, Y_{t}, Y T C_{t}, I_{t}, R X R C_{t}, F D I_{t}, W_{t}, S_{t}\right), & t=1, \ldots, N \\ T I_{t}=F 3\left(c, Y_{t}, Y T I_{t}, I_{t}, R X R I_{t}, F D I_{t}, W_{t}, S_{t}\right) & t=1, \ldots N\end{array}$

Where F1, F2 and F3 are three implicit functions linking simultaneously Australia's income (Y) and China's (TC) and India's incoming tourists (TI) to their theoretically plausible and empirically testable determinants (variables), and $\mathrm{a}, \mathrm{b}$ and $\mathrm{c}$ are three vectors of parameters. In this model, Y may be defined as GNP (gross national product) or, by more popular convention GDP, or income per head of population (Easterly 2007). TC and TI are defined as short-term arrivals (tourists) from China and India respectively, $\mathrm{O}=$ exports or imports or, more conventionally, openness (exports plus imports/GDP). FDI denotes foreign direct investment and I represents Australia's inflation or costs of visiting. SE=trade in services. RXRC and RXRI refer to China's and India's real exchange rates respectively. $S$ is a vector representing shocks or policy reforms. YTC and YTI are China's and India's GDP representing their general economic or demand conditions influencing the supply of tourists. W denotes other economic (fiscal, monetary, trade and tourism policy - see Sala-i-Martin 1991), and S represents noneconomic variables (e.g., country size or population, policy reforms and external shocks - see Johansen 1982, Blake and Sinclair 2003, Tran 2005, and Smeral 2009 for justification) relevant to a country's growth and tourism policy. Importantly for our feasible empirical study, in addition to Y, YTC, YTI, O, FDI, SE, TC, TI and S, data for W must be available and consistent with published time-series data in a standard Kuznets-type accounting framework (e.g., system of national accounts, SNA93/08), or the accounting system of Stone (1988), or the recent World Bank tables.

As (1)-(3) are in implicit form they assume no specific functional form, and therefore are not statistically estimable, and our purpose is ultimately to derive elasticities for their economic variables. Thus, for our empirical implementation, we use planar approximations (thus ignoring higher-order differentials) and invariant transformations (e.g. see Allen 1960, and derivation in Tran 1992) for (1)-(3). The 3-simultaneous equation model (1)-(3) in planar 
approximations can be written more explicitly in stochastic form and in terms of the rates of change for the continuous economic variables (denoted by $y, y t c, y t i, o, f d i, s e, t c, t i, w, i, r x r c$, $r x r i$, and $w$ ) and binary $\mathrm{S}$ of all the included econometrically exogenous and endogenous variables as (for $\mathrm{t}=1, \ldots, \mathrm{N})$

$y_{t}=a 1+a 2 o_{t}+a 3 f d i_{t}+a 4 s e_{t}+a 5 t c_{t}+a 6 t i_{t}+a 7 i_{4}+a 8 w_{t}+a 9 S_{t}+u_{1 t}$

$t c_{t}=b 1+b 2 y_{t}+b 3 y t c_{t}+b 4 i_{t}+b 5 r x r c_{t}+b 6 f d i_{t}+b 7 w_{t}+b 8 S_{t}+u_{2 t}$

$t i_{t}=c 1+c 2 y_{t}+c 3 y t i_{t}+c 4 i_{t}+c 5 r x r i_{t}+c 6 f d i_{t}+c 7 w_{t}+c 8 S_{t}+u_{3 t}$

In (4)-(6), $y$ is growth (the rate of change in real GDP) and the equations are simply linear and interdependent or simultaneous, while $\mathrm{a} 1, \mathrm{~b} 1$ and $\mathrm{c} 1$ are constant terms, a2-a8, b2-b7 and c2c7 are the elasticities, and a9, b8 and c8 are impact parameters. The u's represent other unknown contributing factors not included the model (Frankel and Romer 1999) and are usually designated as the error terms with standard statistical properties.

The model belongs to a class of economic integration models with a number of important and general features that can be summarised as follows (see details in Tran 2007). First, it incorporates testable instantaneous causality in the sense of Granger (1969) or Engle-Granger (1987). Second, it can generate the basic form of the computable general equilibrium/global trade analysis project (CGE/GTAP) models in the Johansen class. Third, as specified in (1)-(3), the model is flexible functionally to deal with any nonlinear or other relationships as no explicit form is nominated (Minier 2007). Fourth, as formulated in (4)-(6), the model is econometrically identified by the order criterion for consistent estimation by such a suitable instrumental-variables (IV) system method as the three-stage least-squares (3SLS) for appropriate policy analysis. In this case, the usual diagnostic tests for ordinary least-squares (OLS) estimation except R-squared and Durbin-Watson statistics on the estimated residuals in these IV estimation cases are not applicable. Finally, the model, expressed as linear in the rates of change of economic and demographic variables, has a dynamic construct (Morley 2009), the empirical findings may in this case be interpreted as long run in the context of Engel-Granger (1987) co-integration or long run causality, if all variables in the equations are integrated by degree one I(1), or as short run causality in the context of Granger (1969) causality if they are all integrated by degree zero I $(0)$.

\section{Data Sources}

\section{EMPIRICAL IMPLEMENTATION AND SUBSTANTIVE FINDINGS}

In addition to the key economic and tourism variables mentioned in Section 2 earlier, $\mathrm{W}$ in the tourism equations (5) and (6) includes conventional demand - theoretically Australia's cost of living and China's and India's real exchange rates, and FDI (Tang et al., 2007). Data for the estimation were obtained from the ABS (2019), ADB (2019), UNCTAD (2019) and USDA-ERS (2019) databases. All economic and trade data are in real values or equivalent. In our study, all original data are obtained or derived as annual, and then transformed to their ratios (when appropriate). The ratio variables include merchandise trade and FDI. Other non-ratio variables include population (a gravity factor proxy for time-series models, Frankel and Romer 1999), inflation, real exchange rates, and qualitative variables representing the occurrence of the economic, financial and other major crises, policy shift or reforms over the period 1992 to 2016.

\section{Variables definition, data processing and stationarity tests}

The qualitative binary variables reflect, in a conventional manner, the major domestic, regional and global event dates, with the assumption of long-term non-decaying effects on growth and 
tourism. All non-binary variables are then converted to their percentage rates of change. The use of this percentage measurement (which is equivalent to log-difference for small changes) is a main feature of our policy modelling and impact approach, as it deals with empirical implementation of the implicit functions (1)-(3) and avoids the problems of restrictive and potentially unsuitable a priori known functional forms (see above), and also of logarithmic transformations for negative data (such as budget (fiscal) deficits, and real interest rates or current account deficits). In addition, in the model, we assume a unidirectional direction of trade, FDI and endogenous tourism to growth in a 'causal' context. That is, the model deals with trade (in goods, FDI and endogenous tourism) and their causal impact on Australia's growth and not vice versa. Major reforms and crises and economic variables that have been identified or assumed as exogenous or acceptable instrumental variables, affecting Australia's growth and China's and India's tourism to Australia, are listed in the empirical findings table in the next section.

The p-values for the ADF/weighted-symmetric unit root test for all variables in the model are given as: Australia's growth $=0.777$, China's growth $=0.653$, Chinese tourism $=0.199$, India's growth $=0.213$, India's tourism $=0.228$, Openness $=0.152, \mathrm{FDI} / \mathrm{GDP}=0.185$, Services $/ \mathrm{GDP}=0.960$, China's RXR $=0.852$, India's RXR $=0.879$, Australian inflation $=0.991$, China's population $=0.081$, India's population $=0.094$. Showing all variables used in the estimation are stationary at the $5 \%$ significance level.

\section{The Estimated Model And Modelling Performance}

To provide insights into China's and India's tourism determination, and the various key contributing factors to growth and endogenous tourism in Australia, the model (4)-(6) has been appropriately estimated, as mentioned earlier, by the 3SLS using the available data for the period 1992-2016. The basic findings are reported in Table 1 below. As indicated, the model is identified according to the order identification tests, and all included (non-binary) variables have been found to be statistically stationary according to the usual unit root tests.

On the statistics reported in the table, all three estimated equations are acceptable in terms of their high R-squared value, lack of evidence on autocorrelation, and the absence of nonstationarity in the residuals. 
Table 1: Impact of China's and India's Endogenous Tourism on Australian Growth. 3SLS Estimates. 1992-2016

\begin{tabular}{|c|c|c|c|}
\hline Variables & Australian Growth & China's Tourism & India's Tourism \\
\hline Const & 0.461 & $-39.617^{*}$ & $178.518^{* * *}$ \\
\hline Trade/GDP & -0.022 & & \\
\hline FDI/GDP & -0.00004 & $0.040^{* * *}$ & 0.0007 \\
\hline Services/GDP & 0.013 & & \\
\hline China Tourism & 0.009 & & \\
\hline India Tourism & $-0.025^{* * *}$ & & \\
\hline Iraq War 1993 & $4.018^{* * *}$ & & \\
\hline 1995 & & $21.952^{* *}$ & \\
\hline Post-AFC 1999 & 0.539 & & $-16.979 * * *$ \\
\hline 2000 & & & -6.770 \\
\hline $\begin{array}{l}\text { New York Terrorist } \\
\text { Attacks } 2001\end{array}$ & $-1.342^{* * *}$ & & \\
\hline 2002 & & & $-30.815^{* * *}$ \\
\hline Iraq War 2003 & & $-307.188^{* * *}$ & \\
\hline Post Iraq War 2004 & & $327.009^{* * *}$ & $21.064^{* * *}$ \\
\hline 2006 & & $-28.657^{* * *}$ & \\
\hline 2007 & & & $-25.925^{* * *}$ \\
\hline GFC 2008/2009 & $-1.375^{* * *}$ & -11.407 & $10.701^{*}$ \\
\hline Australian Growth & & 0.925 & $3.484^{* * *}$ \\
\hline China's Growth & & 1.920 & \\
\hline China's Population & & 22.479 & \\
\hline $\begin{array}{l}\text { China's Real Exchange } \\
\text { Rate }\end{array}$ & & $0.518^{* *}$ & \\
\hline India's Growth & & & -0.415 \\
\hline India's Population & & & $-95.313^{* * *}$ \\
\hline $\begin{array}{l}\text { India's Real Exchange } \\
\text { Rate }\end{array}$ & & & $-0.969 * * *$ \\
\hline Australian Inflation & -0.078 & $2.630^{* *}$ & $5.361^{* * *}$ \\
\hline Euro Recovery 2010 & & $22.929 * * *$ & $-12.241^{* *}$ \\
\hline 2011 & & & -0.185 \\
\hline 2012 & $0.639 * * *$ & & \\
\hline RSQ & 0.859 & 0.823 & 0.901 \\
\hline DW Statistics & 1.721 & 2.626 & 2.659 \\
\hline ADF Test on Residuals & 0.164 & 0.110 & 0.915 \\
\hline
\end{tabular}

Notes: GFC=Global Financial Crisis, RSQ=R-squared, ${ }^{*}=$ Significant at the 10 per cent level. ${ }^{* *}=$ Significant at the 5 per cent level, ${ }^{* * *}=$ Significant at the 1 per cent level, ADF=p-value of the Augmented Dickey-Fuller Unit Root Test. Software used for estimation=TSP-Oxmetrics6.

The modelling performance of the estimated equations as measured by Friedman (1953) 'fruitful outcomes' and Kydland (2006) data-model compatibility or simply 'empirical fit' criterion, is displayed further graphically in Charts 5-7 for Australian growth, China's and India's tourism respectively. 


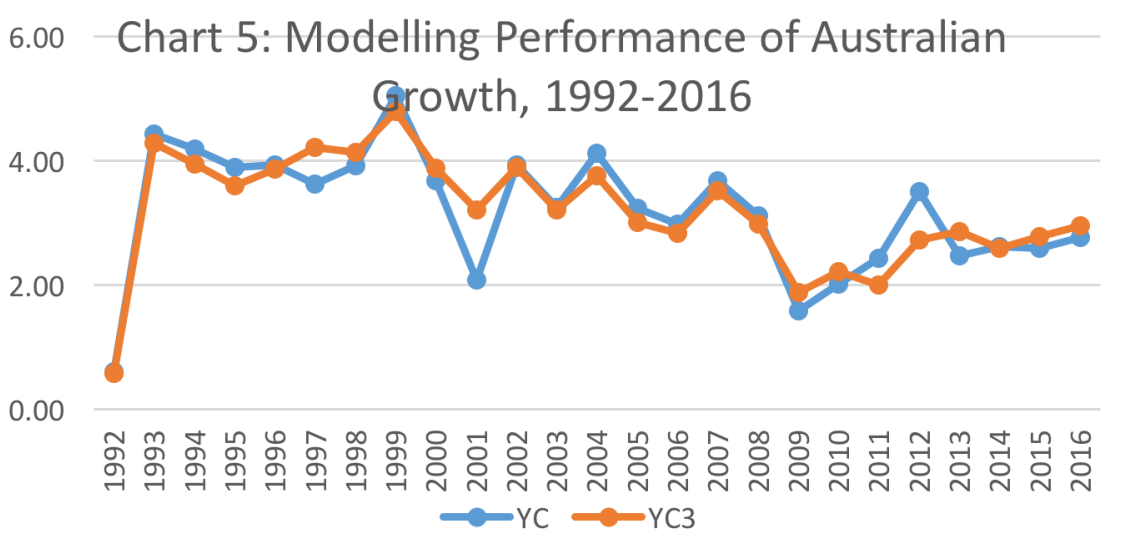

Note: $\mathrm{YC}=$ Australian growth, $\mathrm{YC} 3=\mathrm{YC}$ estimated by $3 \mathrm{SLS}$.

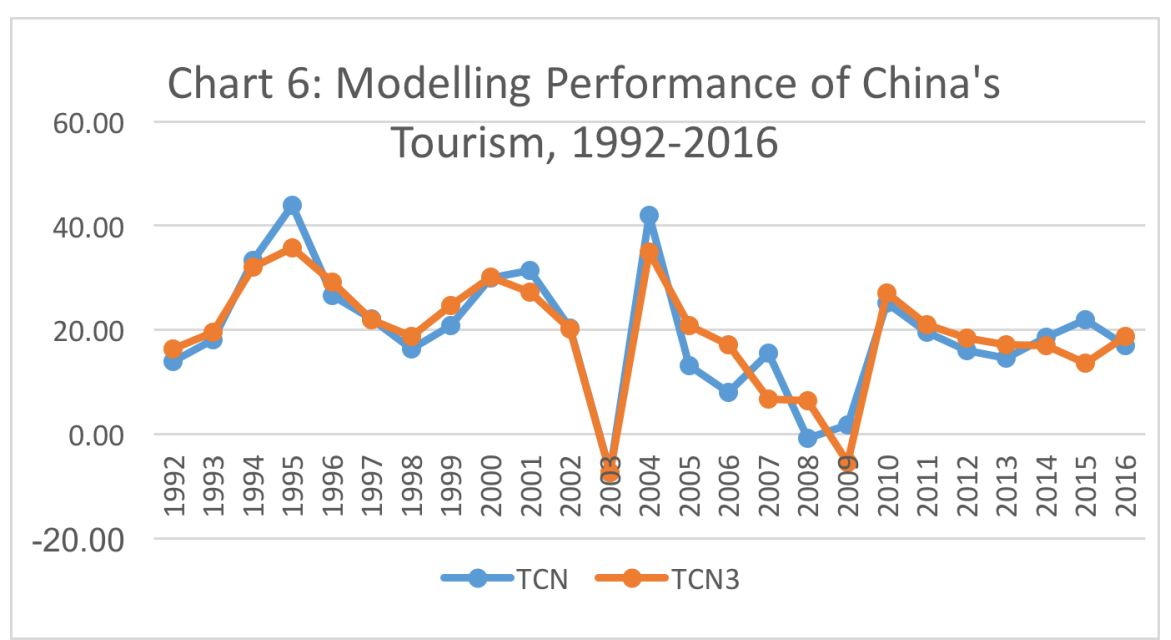

Note: TCN=China's tourism, TCN3= TCN estimated by 3SLS.

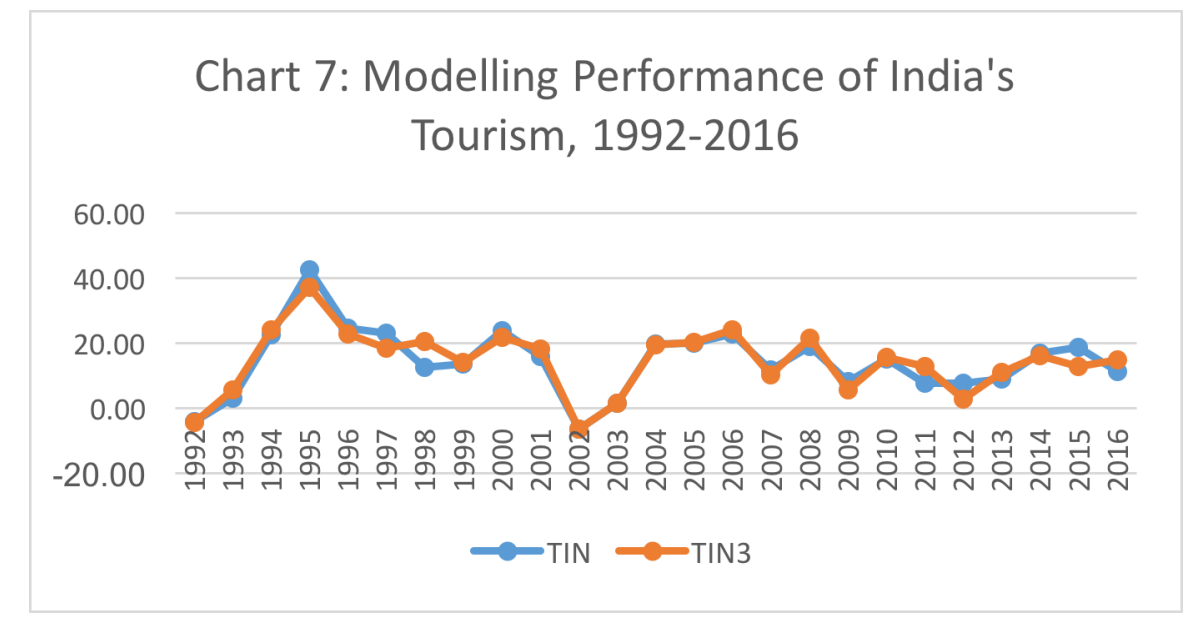

Note: TIN=India's tourism, TIN3= TIN estimated by 3SLS.

In addition, modelling performance is measured by their empirical statistical characteristics, using Theil-MSE decomposition (Pindyck and Rubinfeld, 1998), and given in Table 2. 
Table 2: Friedman-Kydland Modelling Performance Statistical Characteristics of the Estimated Models of Growth and Tourism, 1992-2016 Theil-MSE Decomposition

\begin{tabular}{|c|c|c|c|c|c|}
\hline & $\begin{array}{r}\mathrm{Al} \\
\text { Growt }\end{array}$ & tralian & $\begin{array}{r}\text { Chi } \\
\text { Tourisn }\end{array}$ & & India's Tourism \\
\hline & Data & Model & Data & Model & \\
\hline Mean & 3.188 & 3.188 & 19.274 & 19.274 & $14.408 \quad 14.408$ \\
\hline Stand Dev & 0.994 & 0.920 & 11.884 & 10.738 & $10.303 \quad 9.774$ \\
\hline RSQ & & 0.927 & & 0.907 & 0.949 \\
\hline MSE & & 0.133 & & 23.736 & 10.048 \\
\hline Mean Error & & 0.000 & & 0.000 & 0.000 \\
\hline Bias & & 0.000 & & 0.000 & 0.000 \\
\hline Variance & & 0.039 & & 0.049 & 0.027 \\
\hline Covariance & & 0.961 & & 0.951 & 0.973 \\
\hline
\end{tabular}

Note: RSQ=R-squared, MSE=mean-squared error, Bias+Variance+Covariance $=1$ (See Pindyck and Rubinfeld, 1998).

Other standard diagnostic tests available for OLS estimation and residuals are not appropriate for 3SLS residuals. As assessed by the various modelling diagnostics available and reported in Tables 1-2 and Charts 5-7, the estimated model first performs very well in emulating the volatile movements, peaks and troughs, especially the turning points of Australia's growth and China's and India's tourism data over the sample period. Second, the Theil-MSE findings show the closeness of data, and the model first two moments, and the especially high covariance of 0.961, 0.951 and 0.973 for Australia's growth and China's and India's tourism equations respectively. The model's residuals have also been tested for evidence of unit roots, with a pvalue of 0.164 for Australian growth, and 0.110 and 0.915 for China's and India's tourism establishing statistical stationary. In addition, in the estimated model, the values for $\mathrm{R}^{2}(0.859$ for growth, and 0.823 and 0.901 for China's and India's tourism) and DW (1.721 for growth, and 2.626 and 2.659 for tourisms) appear acceptable and show no first-order autocorrelation problem.

The discussions of the findings and policy implications for China's and India's tourism to Australia, and its impact on Australian growth are based on these empirical findings, and given in Section 5.

\section{GENERAL FINDINGS AND POLICY IMPLICATIONS}

As mentioned earlier (Tran et al., 2018), the literature of tourism and its impact and contribution to economic growth since the early 1960s has been extensive with diverse empirical and simulation findings (see Song et al., 2012). However, in recent years, fast rising globalisation and widespread economic integration (WT0, 2019) has focussed the sources of growth on international trade (or openness), FDI flows, and services (in which tourism is the major component), rather than the traditional production sector of the economy. This requires new directions in research and policy analysis that better reflects these global developments.

This paper makes use of this contemporary focus to develop a new approach to address these developments, the so-called economic integration or system of national accounts (SNA) expenditure approach (Tran, 2004; Tran, 2007; Tran and Limskul, 2013; Tran et al., 2018), to provide substantive evidence for policy analysis in the specific case of China's and India's tourism, and its comparative impact on Australia's growth. The findings by 3SLS estimation using 1992-2016 data of the models (4)-(6) with reported results in Table 1, show interesting results and insights for the impact of globalisation, China's and India's tourism and regional 
and global crises on Australia's growth, and, importantly, the major contributing factors to China's and India's tourism to Australia.

It should be noted that, as these findings are from an endogenous and simultaneous multiequation econometric study with acceptable empirical fit (see above), these time-series databased findings represent another perspective of macro-economic modelling and real-life data, and may not be consistent with expectations or with other findings from alternative approaches such as input-output analysis, CGE simulation, Granger short-term causality, EngleGranger long-term co-integration, or regression analysis (see details of these approaches in Song et al., 2012; Pham et al., 2017).

First, during the period of mainly slow growth in Australia, declining growth in China since the GFC in 2008, and volatile and rising growth in India (see Chart 1), the growth findings show that the age of increasing globalisation with expected higher growth, trade openness (elasticity $=-0.022$ ), FDI (elasticity $=-0.00004$ ), and services (elasticity=0.013) had no significant impact on Australia's growth. An explanation for this could be that Australia, with its long history of being a quite open free-market economy, did not benefit significantly from more globalisation, or from increased trade, FDI and services which had been historically low on a relative international basis. These macro-economic effects in contrast to micro-economic expectations needs further research. However, the findings show that China's tourism to Australia (elasticity $=0.009$ ), in this environment, did have some positive macro-economic impact on Australia, although this effect is weak and statistically not significant. In contrast, India's tourism (-0.025) indicates a statistically significant impact on Australia's growth but in a negative way. This asymmetric impact of China's and India's tourism on Australia is interesting and also requires further research. On the other hand, the two major crises and global development during the sampling period 1992-2016, namely the Iraq War of 1993 (impact=4.018), the GFC (impact=-1.375) and the 2012 recovery (impact=0.639) were seen to have significantly affected Australia's growth. One implication is that while war and the global crisis with wide-spread contagion were expected to be damaging for Australia, the outcomes were however mixed empirically. The regional recovery after the Euro turmoil of 2010 possibly reflects the resilience of the Australian economy and also importance of the closer trade and economic relationship and crisis management between Australia and its neighbouring Asian economies (Tran 2002). Significantly, inflation had some damaging impact (elasticity $=-0.078$ ) on Australia's growth, but the impact is statistically insignificant.

Second, the Chinese and Indian tourism findings not only recognise endogeneity in Australian growth, but also provide useful and important insights into what determines or motivates China's and India's tourism to Australia. As a special de-commodity in the consumer demand basket with international characteristics or attributes, China's tourism is seen as being weakly and positively affected by both Australia's growth (elasticity=0.925) and China's growth (elasticity=0.920). While Australia's growth might not have deterred Chinese tourists, an improvement in China's economy, a deterioration in the renminbi, a rise in the costs of living in Australia and population growth all appear, surprisingly, to have promoted to some extent China's tourism, This is an outcome that would raise international tourism competition, and be of interest to Australia's tourism agencies and policy-makers that may lead to more beneficial tourism innovation in Australia. The findings also indicate importantly that an increase in FDI attracts more Chinese tourists (elasticity=0.040) and the mixed effect of global crises and turmoil on China's tourism to Australia.

Third, in contrast to the Chinese findings, FDI does not seem to have any significant effect (elasticity $=0.0007$ ) on India's tourism to Australia but Australia's growth does and strongly 
(elasticity=3.484). With their country's higher growth however, Indian tourists found it more attractive to seek other touristic destinations (elasticity=-0.415) creating international competition. Also, in contrast to the Chinese findings, a deterioration of the rupees has the expected effect on reducing Indian tourists (elasticity=-0.469), and population growth was not a main driver supporting India's tourism to Australia (elasticity=-95.313) creating again international competition. As in the case of findings for China, tourists from both China and India were not deterred by the high costs of living in Australia (elasticity=2.630 and 5.361). India's tourism to Australia was greatly affected, as in the case of China, by global crises and turmoil and policy reforms.

\section{CONCLUSION}

The paper addresses three important contemporary issues, namely, China's and India's tourism to Australia determination, the comparative contribution of Chinese and Indian tourism to Australia's economic growth, and the lack of rigorous studies taking into account the structure of modern economic integration theory, as applied to these three globalised trade partners. The new approach introduced in the paper, which is particularly consistent with contemporary global economic and trade policy developments and modelling methodological advances, to studying what motivated China's and India's tourism to Australia, their causal differences and their comparative contribution to the Australian economy during the volatile period 1992-2016, has provided a number of interesting results.

These results are useful for further scholarly analysis and also of policy relevance for tourism and economic policy-makers. The main conclusions are: As part of the globalising process, China's and India's tourism to Australia, while growing exponentially in the past decades and currently regarded as a critical sector to Australia's national growth, has been found to exert only a small and asymmetric impact to the Australian economy, at least at the macro-economic level. The open nature of the Australian economy can also provide an explanation for a lack of strong benefits of economic integration in this study. The economic relationships in China's and India's tourism to Australia have been complex, and their benefits depend on Australia's, China's and India's economic demand and supply conditions, and in the shadow of international competition, as well as regional and global crises and reform developments. There is no one-size-fits-all analysis in this context. The findings are supported by rigorous economic-theoretic considerations and robust econometric modelling analysis.

Further research on an enlarged multi-equation economic integration model of endogenous growth and tourism, and extended data, would be desirable to provide further useful insights for scholarly study, and for policy analysis in this important field.

\section{References}

ABS (2019), http://www.abs.gov.au/AUSSTATS/abs@.nsf/DetailsPage/3401.0Jul\%202017?OpenDocument. Accessed 25 Feb 2019.

ADB (2019), https://www.adb.org/publications/series/key-indicators-for-asia-and-the-pacific. Accessed 25 Feb 2019.

Allen, R. G. D. (1960), Mathematical Analysis for Economists, London: Macmillan.

Blake, A. T. and Sinclair, M. T. (2003), “Tourism Crisis Management: US Response to September 11", Annals of Tourism Research 30(4): 813-832.

Easterly, W. (2007), “Was Development Assistance A Mistake?” American Economic Association Meeting, Chicago, 5-7 January 2007.

Engle, R. F. and C. W. J. Granger (1987), “Co-integration and Error Correction: Representation, Estimation and Testing" Econometrica, 55: 251-276. 
ERS-USDA (2019), "International Macroeconomic Data Set",

https://www.ers.usda.gov/data-products/international-macroeconomic-data-set/. Accessed 10 Feb 2019

Frankel, J. A. and D. Romer (1999), “Does Trade Cause Growth?” American Economic Review, 89: 379-399.

Friedman, M. (1953), Essays in Positive Economics, University of Chicago Press.

Gerakis, A. S. (1965), "Effects of Exchange-Rate Devaluation and Revaluation on Receipts from Tourism", International Monetary Fund Staff Papers 12:365-384.

Granger, C. W. J. (1969), "Investigating Causal Relations by Econometric Models and Cross-Spectral Methods" Econometrica, 37: 424-438.

Guthrie, H. W. (1961), "Demand for Tourists' Goods and Services in a World Market", Papers and Proceedings of the Regional Science Association 7:159-175.

Ironmonger, D. S. (1972), New Commodities and Consumer Behaviour, University of Cambridge, Department of Applied Economics Monograph No. 20, Cambridge: Cambridge University Press.

Johansen, L. (1982), "Econometric Models and Economic Planning and Policy: Some Trends and Problems" in M. Hazewinkle and A. H. G. Rinnooy Kan, eds., Current Developments in the Interface:Economics, Econometrics, Mathematics, Boston: Reidel. 91-122.

Kydland, F. E. (2006), “Quantitative Aggregate Economics” American Economic Review, 96(5): 1373-1383.

Lancaster, K. J. (1966), "A New Approach to Consumer Theory”, Journal of Political Economy 84: 132-157.

Minier, J. (2007), "Nonlinearities and Robustness in Growth Regressions”, American Economic Association Meeting, Chicago, 5-7 January 2007.

Morley, C. I. (2009), “Dynamics in the Specification of Tourism Demand Models”, Tourism Economics 15(1): 23-39.

Pham, T. D., Nghiem, S. and Dwyer, L. (2017), “The Determinants of Chinese Visitors to Australia: A Dynamic Demand Analysis", Tourism Management, 63: 268-276.

Pindyck, R. S. and D. L. Rubinfeld (1998), Econometric Models and Economic Forecasts, Sydney: McGraw-Hill, 1998.

Sala-I-Martin, X. (1991), “Comment” in Blanchard, O. J. and S. Fischer (eds.), NBER Macroeconomic Annual 1991, Cambridge, MA: MIT Press, 368-378.

Smeral, E. (2009), "The Impact of the Financial and Economic Crisis on European Tourism", Journal of Travel Research 48(1): 3-13.

Song, H., Dwyer, L., Li, G. and Cao, Z. (2012), “Tourism Economics Research: A Review and Assessment”, Annals of Tourism Research 39(3): 1663-1682.

Stone, R. (1988), "Progress in Balancing the National Accounts" in Ironmonger, D. S., J. O. N. Perkins, and V. H. Tran (eds.), National Income and Economic Progress: Essays in Honour of Colin Clark, London: Macmillan.

Tang, S., Selvanathan, E. A. and Selvanathan, S. (2007), "The Relationship between Foreign Direct Investment and Tourism: Empirical Evidence from China", Tourism Economics, 13(1): 25-39.

Tran, V.H. (1992), “Modelling Output Growth: A New Approach” Economics Letters, 38: 279-284.

Tran, V. H. (2002a), “Korea, China and Japan's Trade with the World and Its Impact on New Asian Regionalism ASEAN+3" Paper presented at the Joint Conference of the Association of the Korean Economic Studies, Korea Development Institute, and Research Center for International Economics, Yonsei University, Seoul, 21-22 July 2002.

Tran, V. H. (2002b), Economic Crisis Management, Mass.: Edward Elgar.

Tran, V. H. (2002c), "New Asian Regionalism and ASEAN+3 Free Trade Agreement: Theoretical and Empirical Foundation, Policy Challenges and Growth Prospects" Chulalongkorn Journal of Economics (Thailand), 14(3): 366384.

Tran, V. H. (2004), "Korea's Trade, Growth of Trade and the World Economy in Post-crisis ASEAN+3 Free Trade Agreement: An Econometric and Policy Analysis", Journal of the Korean Economy, 5(2): 73-108.

Tran, V. H. (2005), "Modelling the Impact of China's WTO Membership on Its Investment and Growth: A New Flexible Keynesian Approach" (with Comment), in G.S. Heiduk and Karyiu Wong (eds), WTO and World Trade, New York: Physica-Verlag.

Tran,V. H. (2007), Causal Empirics and Political Economy of Official Development Assistance and Development in Asia: The Case of Vietnam, Journal of the Korean Economy, 8(1): 91-119. 
Tran, V. H. and K. Limskul (2013), "Economic Impact of CO2 Emissions on Thailand's Growth and Climate Change Mitigation Policy: A Modelling Analysis", Economic Modelling, 33: 351-358.

Tran, V. H., Turner, L. and Vu J. (2018), "Economic Impact of Chinese Tourism to Australia: A New Approach", Tourism Economics, 26(4): 677-689.

Tran V. H. and Vu, J. (2018), 'Economic Impact of Vietnam's Tourism on Australia: An Econometric Study', International Journal of Management and Applied Science, 4(9): 41-49.

UNCTAD (2019), “Data Center”, http://unctadstat.unctad.org/EN/. Accessed 10 Feb 2019.

WTO (2019), "Regional Trade Agreements", https://www.wto.org/english/tratop_e/region e/region e.htm. Accessed 2 March 2019. 